\title{
Benefits of caloric restriction in the myenteric neuronal plasticity in aging rats
}

\author{
JOICE N.B. PEREIRA ${ }^{1}$, RENATA B. MARI ${ }^{2}$, SANDRA R. STABILLE ${ }^{3}$, \\ HAROLDO G. DE FARIA ${ }^{4}$, THAIS F.M. MOTA ${ }^{5}$ and WALTER M. FERREIRA ${ }^{6}$ \\ ${ }^{1}$ Departamento de Cirurgia, Faculdade de Medicina Veterinária e Zootecnia, Universidade de São Paulo, \\ Avenida Professor Dr. Orlando Marques de Paiva, 87, Cidade Universitária, 05508-270 São Paulo, SP, Brasil \\ ${ }^{2}$ Universidade Estadual Paulista "Júlio de Mesquita Filho", Campus Litoral Paulista, \\ Praça Infante Dom Henrique, s/n, Parque Bitaru, 11330-900 São Vicente, SP, Brasil \\ ${ }^{3}$ Departamento de Ciências Morfológicas, Universidade Estadual de Maringá, \\ Avenida Colombo, 5790, 87020-900 Maringá, PR, Brasil \\ ${ }^{4}$ Biotério Central, Universidade Estadual de Maringá, \\ Avenida Colombo, 5790, 87020-900 Maringá, PR, Brasil \\ ${ }^{5}$ Departamento de Biologia, Universidade Estadual de Maringá, \\ Avenida Colombo, 5790, Bloco G-80, 87020-900 Maringá, PR, Brasil \\ ${ }^{6}$ Escola de Veterinária da Universidade Federal de Minas Gerais, \\ Avenida Antônio Carlos, 6627, Caixa Postal 567, 30161-970 Belo Horizonte, MG, Brasil
}

Manuscript received on February 11, 2013; accepted for publication on May 5, 2014

\begin{abstract}
Aging is a biologic process characterized by progressive damage of structures and functions of organic systems. In gastrointestinal tract, it can involve enteric nervous system, which plays an important role in digestion and absorption of nutrients, causing hastening of intestinal transit thus reducing its absorptive function. Caloric restriction has been used in several studies with the intention of delaying deleterious effects of aging. This study aimed to evaluate the effects of caloric restriction on myenteric neurons of ileum by aging in rats. 30 Wistar rats were grouped as follows: GI (animals aged 6 months fed with normal diet), GII (animals aged 18 months fed with normal diet) and GIII (animals aged 18 months subject to $31 \%$ of caloric restriction). The rats of the GI group were euthanized at 6 months of age and after experimental period of 12 months animals of the group GII and GIII were euthanized, the ileum of all groups were collected, measured and processed by NADPH-dp and Acetylcholinesterase. Quantitative analysis of neurons revealed that aging promotes the increasing of myenteric neurons NADPH-dp and reduces Acetylcholinesterase neuronal population. However, in the cellular profile area, were not observed significant differences between the groups. The caloric restriction has been efficient and can be used preventively because it minimizes quantitative changes associated with aging on ileum myenteric plexuses.
\end{abstract}

Key words: aging, caloric restriction, myenteric plexus, small intestine.

\section{INTRODUCTION}

The increasing of elderly population is considered a global phenomenon (Kapteyn 2010). According to

Correspondence to: Joice Naiara Bertaglia Pereira

E-mail: joicebertaglia@usp.br the United Nations the percentage of people aged sixty years or more will be double by the year 2050 (UN 2009). Many factors have contributed to the increasing of life expectancy, some of which are strictly related with medical advances, expansion 
of basic sanitation services, practices of physical activity and improvement of feeding habits (Almeida and Fernandes 2001).

Aging is characterized as a biological process with progressive functional and structural damage of many organic systems (Riggs et al. 2004). This process increases the probability of degenerative diseases and is hastened by an interaction between genetic factors (Kenyon 2005). All these factors together especially contribute to increase in the free radical production (Letiembre et al. 2007), thus causing functional and structural alterations in organs (Lukiw 2007).

Some authors reported that in the aging process many changes can occur in the digestive system, such as, decreasing of esophagus motility (Butt et al. 1993) and consequently decreasing of bacterial colonies (Madsen 1992), delayed gastric depletion(Brogna et al. 1999) and increasing of intestinal transit (Anuras and Leoning-baucke 1984). During the entire process of aging can be observed from changes lighter in the gastrointestinal tract, such as constipation, even more serious conditions such as intestinal obstruction (Shamburek and Farrar 1990).

The GI tract is innervated by intrinsic neurons of the enteric nervous system (ENS) (Furness and Costa 1987, Furness 2006) as well as by extrinsic neurons from sympathetic, parasympathetic and sensory nerves. The ENS together with its two main plexuses (the myenteric and submucosal), is responsible for the control of the motility, blood flow and secretion of the digestive tube, as it acts in the digestion and absorption of nutrients (Phillips and Powley 2007). The impairment of enteric neurons, caused by aging, usually implies in the occurrence of diseases and disorders in the GI tract(Hazzard et al. 1999).

The decrease in the total number of enteric neurons, particularly in the myenteric plexus, have been related. These authors also reported that aging influences the changing of the density of nerve fibers, and, in the structure of the enteric ganglia(Souza et al. 1993, Phillips and Powley 2001, Mari et al. 2008).
Some studies have been performed with the objective of delaying the deleterious effects of aging in organic systems, thus increasing, among these studies, the caloric restriction (CR) has been investigated (Holloszy and Fontana 2007).

$\mathrm{CR}$ is defined as a moderate reduction (20$40 \%$ ) of calorie intake when compared with an $a d$ libitum diet without damage in the maintenance of essential nutrients (Piper and Bartke 2008). Studies with rodents have shown that many diseases and disorders associated with age decrease visibly by CR usage (Weindruch and Walford 1988, Masoro 2002) and that the CR reduces the degeneration of neurons in animal models suffering from Parkinson disease (Mattson 2000).

The mechanisms of action responsible for the benefic effects of CR include changes in gene expression, reduction of oxidative stress, decreased metabolism and increased capacity of DNA repair (Sohal and Weindruch 1996, Lee et al. 1999).

The studies on ENS have demonstrated that CR promotes reduction of enteric neuronal death during aging (Cowen et al. 2000). In the ENS, authors reported that $\mathrm{CR}$ minimized the deleterious effects on total population and nitrergic myenteric neurons in the duodenum of aged rats (Porto et al. 2012).

Owing to the increase in the elderly population and the incessant search for alternatives that reduce the deleterious effects of aging, this study aimed to evaluate the effects of CR in the plasticity of myenteric neurons NADPH-diaforase positive (NADPH-dp) and Acetilcolinesterase positive neurons (AchE+) in the ileum of rats under aging process.

\section{MATERIALS AND METHODS}

All the procedures of this study regarding the manipulation and use of animals were in accordance with the ethical principles adopted by the Brazilian School of Animal Experimentation (COBEA) and approved by the Faculty of Veterinary Medicine and Animal Science of the Sao Paulo University Bioethics committee under the Protocol number 1132/2007. 
Thirty male Wistar rats (Rattus norvegicus) were distributed into three groups:

GI: six-month-old animals fed with a normal diet (Diet A) from weaning period (21 days) to six months-old.

GII:18-month-old animals fed with a normal $\operatorname{diet}$ (Diet A) from weaning to 18 months-old.

GIII:18-month-old animals fed with a diet with $31 \%$ caloric restriction (Diet B) starting as of six months of age.

In this study, two isoproteic diets were performed (diet A and B) (Table I). Diet A (Nuvital ${ }^{\circledR}$ ) was considered standard for laboratory animals and was

TABLE I

The percentages and chemical compositions of the experimental diets with respect to their energy levels.

\begin{tabular}{|c|c|c|c|}
\hline Ingredients & Unit & Diet A & Diet B \\
\hline Corn & $\mathrm{Kg}$ & 42.711 & - \\
\hline Soybean & $\mathrm{Kg}$ & 36.101 & 46.200 \\
\hline Wheat & $\mathrm{Kg}$ & 11.482 & 3.200 \\
\hline Dicalcium phosphate & $\mathrm{Kg}$ & 2.035 & 2.700 \\
\hline Inert & $\mathrm{Kg}$ & - & 23.750 \\
\hline Calcareous & $\mathrm{Kg}$ & 0.136 & 0.300 \\
\hline Starch & $\mathrm{Kg}$ & - & 19.050 \\
\hline Soybean oil & $\mathrm{Kg}$ & 2.735 & - \\
\hline Salt & $\mathrm{Kg}$ & 0.300 & 0.300 \\
\hline Vitamin premix $^{1}$ & $\mathrm{Kg}$ & 1.000 & 1.000 \\
\hline Mineral premix ${ }^{2}$ & $\mathrm{Kg}$ & 3.500 & 3.550 \\
\hline Gross energy & $\mathrm{Kcal} / \mathrm{kg}$ & 3900 & 2700 \\
\hline Crude protein & $\%$ & 22.0 & 22.0 \\
\hline Crude fiber & $\%$ & 4.0 & 3.0 \\
\hline Calcium & $\%$ & 0.70 & 0.9 \\
\hline Total phosphorus & $\%$ & 0.80 & 0.8 \\
\hline
\end{tabular}

${ }^{1}$ Composition per $\mathrm{kg}$ of product: Vit. A, 400,000 UI; Vit. D3, 100,000 UI; Vit. E, 7500mg; Vit. K1, 75mg; Vit. B12, $2500 \mathrm{mcg}$; Folic acid, 200mg; nicotinic acid, 3000mg; biotin, $20 \mathrm{mg}$; calcium pantothenate $1600 \mathrm{mg}$; pyrodoxin- $\mathrm{HCl}, 700 \mathrm{mg}$; riboflavin, $600 \mathrm{mg}$; tiamine $\mathrm{HCl}, 600 \mathrm{mg}$.

${ }^{2}$ Composition per kg of product: boron, $14.26 \mathrm{mg}$; calcium, 142.94; chlorine, 44.9; copper, 172.41; chrome, 28.65; sulfur, 8.60; iron, $1000 \mathrm{mg}$; fluoride, $28.72 \mathrm{mg}$; phosphorus, $44.61 \mathrm{mg}$; iodine, 5.93mg; lithium, 2.85mg; magnesium, $14.48 \mathrm{mg}$; manganese, $300 \mathrm{mg}$; molybdenum, $4.32 \mathrm{mg}$; nickel, 14.31 ; potassium, $102.81 \mathrm{mg}$; selenium, $4.28 \mathrm{mg}$; silicon, $143.26 \mathrm{mg}$; sodium, $29.38 \mathrm{mg}$; vanvanadium, $2.87 \mathrm{mg}$; zinc, $860 \mathrm{mg}$. provided to the animals of GI and GII groups. Diet $\mathrm{B}$ was provided to the animals of the GIII group; in this group of animals the crude energy was reduced by $31 \%(2700 \mathrm{kcal} / \mathrm{EB} / \mathrm{kg})$ compared to the $\operatorname{diet} \mathrm{A}$ (3900 kcal/EB/kg).

The animals were individually housed in polypropylene boxes, provided with food and drink under controlled environmental conditions for temperature $\left(24 \pm 2^{\circ} \mathrm{C}\right)$ and lighting (12 hours light cycle / 12 hours dark cycle); water was given to the animals ad libitum.

To determine the amount of food to be provided daily during the experiment, all the groups of animals were kept in a seven-day adaptation process. During this process, the animals were provided with a normal diet and water ad libitum. The average of the daily consumption during the adaptation phase was used as the daily amount of chow that was administered throughout the duration of the first month of the experiment. Thus, the amount supplied to the animals of GIII was adjusted monthly based on the average of consumption of the animals from GII. This was necessary to ensure that the animals fed a low-calorie diet compensate with increased intake.

After the adaptation period, the animals of the GII were fed with a normal diet (A) with a chemical composition based on the dietary references for laboratory animals, established by the National Research Council (NRC 1995). The GIII animals were fed a diet with $31 \%$ less energy than that compared to normal diet. The animals of GII and GIII were subjected to the experiment of six to 18 months of age.

At the end of the experiment (12 months), the animals of the groups GII and GIII fasted for 12 hours and were than anesthetized intraperitoneally with Thiopental ${ }^{\circledR}$ (40 mg/kg of body weight). The rats of the group GI at six months of age anesthetized were the same way. After, the laparotomy was performed, were collected and measured the retroperitoneal and periepididimal fat together, and the distal ileum of each animal was removed, along the ileocecal fold and ileocecal union. 
Throughout development, changes in the dimensions of the gastrointestinal tract segments can cause a dilution or concentration of neuronal density, which may result in the reduction of, or an apparent increase in, the number of enteric neurons. Therefore, the ileum was measured using a millimeter ruler. One face of the segments was copied onto white paper to determine the intestinal surface area. The drawings were scanned onto millimeter paper, and the area $\left(\mathrm{cm}^{2}\right)$ was determined using the Pro-Plus 3.0.1 ${ }^{\circledR}$ image analysis software.

Five ileum from each group were used for acetylcholinesterase histochemistry and the remaining five samples from each group were subjected to NADPH-diaphorase histochemistry.

\section{Detection of Acetilcolinesterase Positive Myenteric}

NEURONS (ACHE+) (KARNOVSKY AND RoOTS 1964)

The ileum were collected and washed firstly in saline solution and later in $4 \%$ paraformaldehyde in phosphate buffer; intestinal samples remained immersion-fixed in this fixative for one hour at $4^{\circ} \mathrm{C}$, and later rinsed in Krebs solution containing hyaluronidase (2000 RTU) and tetraisopropil phyrophosphoramide(Isso-OMPA) for twelve hours. The incubation was performed for a period of 24 hours at $4^{\circ} \mathrm{C}$ in medium containing $0.17 \mathrm{M}$ acetylcholine, $6.5 \mathrm{~mL}$ phosphate buffer $(0.1$ $\mathrm{M}, \mathrm{pH} 7.1), 0.5 \mathrm{~mL}$ of sodium citrate $(100 \mathrm{mM}), 1 \mathrm{~mL}$ of copper sulphate $(30 \mathrm{mM}), 1 \mathrm{~mL}$ of distilled water and $1 \mathrm{~mL}$ of potassium ferricyanide $(5 \mathrm{mM})$ adding tetraisopropil phyrophosphoramide and hyaluronidase.

DETECTION OF POSITIVE NADPH-DIAPHORASE MYENTERIC

NEURONS (NADPH-DP) (SCHERER-SINGLER ET AL. 1983)

To detect the nitrergic myenteric neurons, the ileums obtained from five animals of each group were rinsed and filled with PBS ( $\mathrm{pH}$ 7.4). The sections were sutured to retain the filling solution in situ. Each sample of ileum was soaked in two baths of PBS (10 minutes each) followed by permeabilization in PBS with $0.3 \%$ Triton X-100 in sodium phosphate buffer ( $\mathrm{pH}$ 7.3) for 10 minutes; the samples were then immersed in two baths of PBS for10 minutes each. To observe the NADPHdp myenteric neurons after washing process, each ileum was incubated in reaction medium containing $50 \mathrm{mg}$ NBT, $100 \mathrm{mg} \beta$-NADPH and 0.3\% Triton $\mathrm{X}-100$ in Tris-HCl (0.1 M, pH 7.6) buffer for two hours. The terminal portions of each ileum were released, and the duodenum was immersed in $4 \%$ paraformaldehyde for fixation and storage.

After fixation, each ileum was incised along the longitudinal axis of the mesenteric insertion and subjected to similar micro dissection procedures, for removal of the mucosa and submucosa to obtain wholemounts samples; each sample was then mounted on glass slides using Permount ${ }^{\circledR}$ synthetic resin.

NEURONAL QUANTIFICATION $\left(\mathrm{MM}^{2}\right)$

To quantify the population of the myenteric neurons stained with Acetylcholinesterase (AchE+) and NADPH-diaphorase (NADPH-dp) were use the whole-mount preparation. The neuronal density $/ \mathrm{mm}^{2}$ of the ileum was determined by light microscope (Olympus BX50/Hamburg/Germany) accoupled to a high-resolution digital camera AxioCam HR (Zeiss ${ }^{\circledR} /$ Jena/ Germany) and photographed in a 40X objective.

The quantitative analysis for each wholemount preparation was adapted from a test system containing 60 equally spaced fields by cut samples of all regions along the circumference of the ileum. A test system using inclusion and exclusion lines was also applied to the images taken. The neurons within the boundaries of the test area and on the top and right edges were counted, and the neurons on the bottom and left edges were excluded.

Morphometry of the Neuronal Cell Body AreA $\left(\mathrm{MM}^{2}\right)$

The measurement of the cell body (CB) area of the ileum myenteric neurons was performed using the computerised image analysis software Image-Pro Plus 3.0.1. (Media Cybernetics, Silver Spring, Maryland, USA). Images of the neurons taken for quantitative analysis were used for 
morphometric analysis. The $\mathrm{CB}$ area of 100 neurons was measured for each animal of each group.

\section{STATISTICAL ANALYSIS}

The statitical analsyis relative to the body weight and weight of the retroperitoneal and periepididimal fat of the animals was evaluated by T-student test. The morphoquantitative data of the NADPH-dp and AchE+ myenteric neurons, and, intestinal measurements were analyzed by Kruskal-Wallis test. The results were expressed as the average \pm standard deviation with a significance level of $5 \%$.

\section{RESULTS}

During the experimental period (12 months), the animals were weighed daily and the data referring to the average of the initial and final weight of each group are presented in Table II. From the third month of weighing, a significant reduction $(\mathrm{p}<0.05)$ in the weight average $(\mathrm{g})$ of the animals of GIII is clearly visible when compared to the animals of GII.

The weight of the retroperitoneal and periepididimal fat together was higher in animals fed the diet with $3900 \mathrm{Kcal} / \mathrm{EB}(12.3 \pm 1.2 \mathrm{~g})$ compared to animals fed diet $2700 \mathrm{kcal} / \mathrm{EB}(9.1 \pm 1.5 \mathrm{~g})$. However this difference was not significant ( $\mathrm{p}>0.05)$.

It was observed in all groups studied (GI, GII e GIII), that the myenteric neurons AchE+ e NADPH$\mathrm{dp}$ (Figure 1) was predominantly grouped in ganglia interconnected by bundles of nerve fibers. No changes caused by aging were observed in the morphological analysis of whole-mount preparations.

The intestinal area $\left(\mathrm{mm}^{2}\right)$ did not differ ( $p>0.05$ ) with age or $\mathrm{CR}$, as shown by comparing groups GI (87.1 \pm 9.9$)$, GII $(91.1 \pm 15.5)$ and GIII

TABLE II

Initial and final average of the weight \pm standard deviation (grams) of the rats from GII group (without caloric restriction) and GIII group (with caloric restriction) during the experimental period (12 months).

\begin{tabular}{lccc}
\hline & GI & GII & GIII \\
\hline Initial weight (06 months) & $397 \pm 1.2$ & $398 \pm 0.9^{\mathrm{a}}$ & $396 \pm 1.1^{\mathrm{a}}$ \\
Final weight (18 months) & - & $570 \pm 0.82^{\mathrm{a}}$ & $514 \pm 0.9^{\mathrm{b}}$ \\
\hline
\end{tabular}

${ }^{\mathrm{a}, \mathrm{b}}$ Average with different letters in the row differ $(\mathrm{p}<0.05)$ by T- Student test.
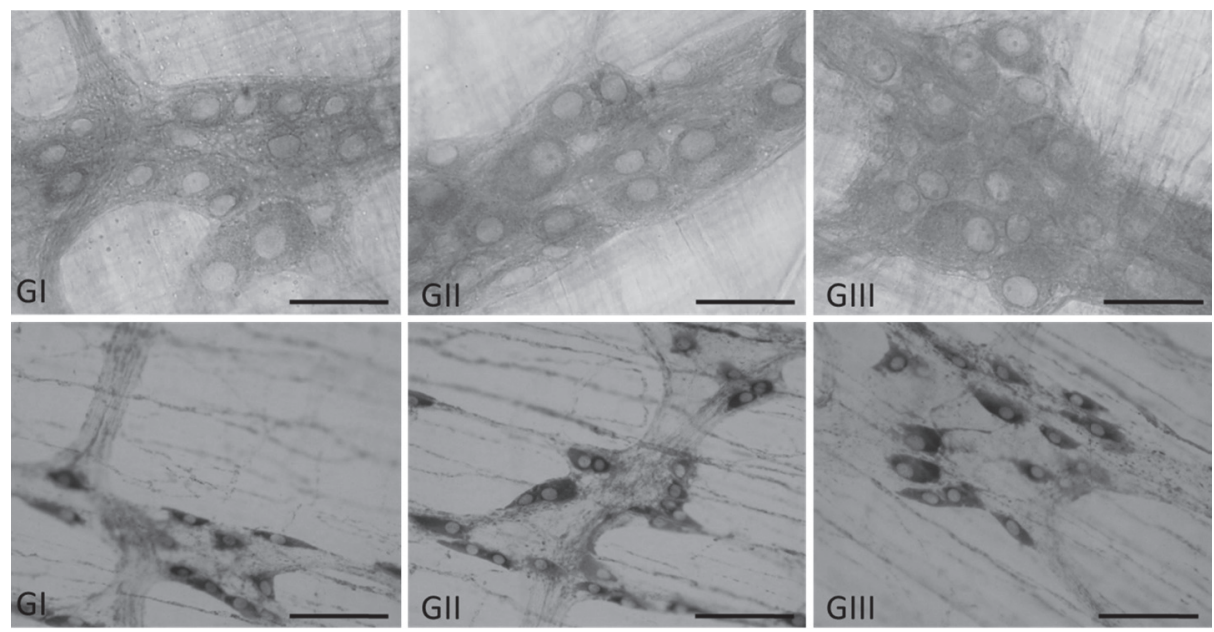

Figure 1 - Photomicrograph of myenteric neurons AchE+ (top) and NADPH-dp (bottom) in the ileum of GI, GII and GIII rats. (Scale bars: $100 \mu \mathrm{m}$ ). 
(86.4 \pm 18.8$)$. Therefore, there was no need to apply correction factors to the results obtained from the quantification and analysis of neuronal morphology.

\section{NEURONAL DENSITY}

The data referring to the density of the neurons NADPH-dp and AchE+ per $\mathrm{mm}^{2}$ from the ileum of the three groups studied are presented in Table III.

When GII (18 months) was compared with GI $(6$ months $)$, a significant increase $(p<0.05)$ was observed in the density of myenteric neurons NADPH-dp during aging process. However, this increase $(p<0.05)$ was minimized in animals subject to caloric restriction (GIII).
Aging promotes a significant reduction $(p<0.05)$ in the density of AchE+ neurons ileum of the rats when compared to GI and GII. It was observed that the animals under caloric restriction diet (GIII) presented a significant increase $(\mathrm{p}<0.05)$ in the density of myenteric neurons (49 and 59\% higher) when compared to GI and GII, respectively. Morphometry of the Cellular Profile

Regarding the cellular profile area of myenteric neurons $\left(\mu \mathrm{m}^{2}\right)$, no statistical differences $(\mathrm{p}>0.05)$ were observed among the groups (GI, GII and GIII), in two hystochemistry techniques utilized (NADPHdiaforase and Acetylcholinesterase) (Table IV).

TABLE III

Average of the neurons density NADPH-dp and AchE+ per $\mathbf{m m}^{2}$ from the ileum of the rats of the GI (six months), GII (diet A) and GIII (diet B) groups.

\begin{tabular}{|c|c|c|}
\hline \multirow{2}{*}{ Animal Groups } & \multicolumn{2}{|c|}{ Neuronal density $/ \mathbf{m m}^{2}$} \\
\hline & NADPH-dp & $\operatorname{AchE}+$ \\
\hline GI & $45.02 \pm 5.25^{b}$ & $142.89 \pm 26.95^{b}$ \\
\hline GII & $55.81 \pm 5.21^{\mathrm{a}}$ & $133.33 \pm 31.56^{\mathrm{c}}$ \\
\hline GIII & $39.17 \pm 8.26^{\mathrm{b}}$ & $213.23 \pm 27.26^{\mathrm{a}}$ \\
\hline
\end{tabular}

a,b,c Average with different letters in the row differ $(\mathrm{p}<0.05)$ by Kruskal-Wallis test.

TABLE IV

Measurements average $\left(\mu \mathrm{m}^{2}\right)$ of the cellular profile area of the neurons NADPH-dp and AchE+ of animals from GI, GII, GIII groups.

\begin{tabular}{ccc}
\hline \multirow{2}{*}{ Animal Groups } & \multicolumn{2}{c}{ Cellular profile area $\left(\boldsymbol{\mu \mathbf { m } ^ { 2 } )}\right.$} \\
\cline { 2 - 3 } & NADPH-dp & AchE+ \\
\hline GI & $84.28 \pm 28.92^{\mathrm{a}}$ & $140.14 \pm 34.87^{\mathrm{a}}$ \\
GII & $74.16 \pm 24.76^{\mathrm{a}}$ & $141.37 \pm 35.08^{\mathrm{a}}$ \\
GIII & $76.38 \pm 25.13^{\mathrm{a}}$ & $145.35 \pm 37.01^{\mathrm{a}}$ \\
\hline
\end{tabular}

${ }^{a}$ Average with similar letters in the same column are not different $(\mathrm{p}<0.05)$ in the Kruskal-Wallis test. 
In the three groups studied, the AchE+ neurons presented cellular profile area predominantly between 100 to $200 \mu \mathrm{m}^{2}$, whereas the NADPH-dp neurons revealed a cellular profile area lower than $100 \mu \mathrm{m}^{2}$.

\section{DISCUSSION}

The amount of food (diet A and B) supplied to the GI and GII are controlled to ensure that animals can not compensate for the GIII calorie restriction with an increase in food intake.Therefore, a significant reduction ( $\mathrm{p}<0.05$ ) of $8 \%$ in the body weight average (g) was observed in the animals of GIII when compared to the GII group; this results confirm the benefic effects of the $\mathrm{CR}$ in the control of body weight during aging.

Studies have demonstratedd reduction of $20 \%$ of body weight and fat in mice aged 12 months subject to $50 \%$ of food restriction for four weeks (Papa et al. 1997, 2002). Additionally, authors demonstrated that the amount of body fat in rats subject to CR from 12 to 28 months of age was clearly different from the rats fed ad libitum (Bailey et al. 1993).

The weight of the retroperitoneal and periepididymal fat, measured together, was higher ( $p>0.05$ ) in group GII fed diet A than that compared with animals fed diet B. Similar results reported a reduction in body fat in several experiments with animals of other species. Pekas (1993) studying with feed restriction in pigs also observed a reduction in body fat of animals. In birds, Fontana et al. (1993) and Palo et al. (1995) reported a reduction in carcass fat when animals were subjected to food restriction.

The reduction in body fat is the result of CR imposed on animals, demonstrating that there is a mobilization of this energy reserve. Albeit less intense, this effect also occurred in relation to muscle mass of animals, perceived by the lower weight of the animals submitted to the RC, especially at the beginning of the experiment.

No morphological changes were observed in the myenteric plexuses of the three groups of animals studied; this result indicates that no interference occurred during aging and $\mathrm{CR}$ in the spatial organization of the myenteric plexus. The inexistence of morphological changes in the plexus of rats during aging process has also been reported in previous studies (Natali et al. 2000, Mari et al. 2008, Porto et al. 2012).

In the present study, the area of the ileum $\left(\mathrm{mm}^{2}\right)$ was verified to avoid erroneous interpretations of the morphometric and quantitative data. In cases of altered intestinal dimensions, a correction factor corresponding to the ratio between the area of the intestine in a young animal and that of an elderly animal was used to correct quantitative data(Phillips and Powley 2001). However, because the intestinal dimensions in the present study did not differ with age or CR ( $p>0.05)$, the use of a correction factor was not necessary.

Similar results on the intestinal area was observed in the duodenum of aged rats, where no change in the area of the duodenum was observed with aging and CR (Porto et al. 2012).

When GII (18 months) and GI (six months) were compared a considerable increase of $19 \%$ in the density of nitrergic neurons during aging was observed; this increase of the nitrergic population with aging was also observed in the duodenum (Porto et al. 2012), and colon of rats (Belai et al. 1995, Cowen et al. 2000).

The increase observed in the nitrergic population during aging suggests a high resistance to cellular death of this neuronal population when compared to other neuronal sub populations (Santer 1994).

The NO is responsible for relaxing the smooth intestinal muscles, contributing in a secondary way, towards reducing the intestinal transit and increasing the absorptive capacity of fluids by the intestinal epithelium (Sanders and Ward 1992, Mizuta et al. 1999).

During aging process, the increase of NO production promotes disorders in the intestinal motility, characterized by reduction in the frequency, amplitude and duration of the propulsive contraction of the gastrointestinal tract (Cortesini et al. 1995).

Studies regarding the protective or harmful effect of the NO on neurons have been widely debated (Calabrese et al. 2007). It is known that in many 
neurodegenerative diseases such as the amyotrophic lateral sclerosis and Parkinson's disease, high concentration of NO may lead to cellular death by apoptosis (Singh and Dikshit 2007).

Cirilo et al. (2013), in studies with 50\% dietary restriction and aging, analyzed myenteric population $\mathrm{HuC} / \mathrm{D}$, subpopulation nNOS and glial cells in rats 7-12 months old, and found that aging did not cause changes in any of the populations studied, however, with dietary restriction, a significant decrease of the population $\mathrm{HuC} / \mathrm{D}$ and glial cells, without affecting the population nitrergic. In addition, with aging beyond death of neurons, is reported quantitative decrease in the population of enteric glia, which plays an important role in maintaining the enteric nervous system (Phillips et al. 2004). Thus, glial cell death would lead to a reduction of neurotrophic factors during aging (Dolatshad et al. 2001), contributing to neuronal loss myenteric.

However, in this study it was observed that in the NADPH-dp myenteric population the CR revealed minimizing the increase of the density that occurs in aging process. Such effect may be associated to a possible maintenance of the neurotrophic factors or to a high resistance of free radicals promoted by CR (Johnson et al. 1998, Wade and Cowen 2004).

Regarding the AchE+ neurons, a reduction of $49 \%$ in the neuronal density during aging were observed. Supporting this evidence, some authors reported on a reduction in the neurons that reveal acetylcholine in the small intestine of animals under aging process (Cowen et al. 2000, Phillips et al. 2003, Porto et al. 2012). The cholinergic neurons are responsible for contraction of muscle fibers, so, its reduction leads to a reduction in the intestinal function (Xiong et al. 1995).

In our study we observed that the CR acted on neuronal vulnerability at the expense of the aging process, significantly increasing the density of $\mathrm{AchE}+$ neurons.

Corroborating our results, in the duodenum of rats to CR group observed a significant increase in the population myenteric AchE+ (Porto et al. 2012). According to authors the death of neurons during aging in the nervous central system is attributed to the increasing of free radicals (Merry 2002).

During was reported on the increase of oxidative stress aging in the myenteric neurons population; additionally these authors also determine that the extensive absorptive surface of the intestine contributes to increase the level of exposure of the free radicals in the gastrointestinal tract (Thrasivoulou et al. 2006).

Changes in the cellular profile area of the myenteric neurons are reported under experimental conditions involving diabetes mellitus (Furlan et al. 2002), under nutrition (Castelucci et al. 2002) and dietary restriction (Cirilo et al. 2013). According to authors the increase of neurons size is usually confirmed during animal development (Gabella 1971). Thus, in considering the neuronal changes observed in the aging process, we can check the possible effects of CR on this parameter.

No changes in the cellular profile area with regards to aging and/or CR were observed in both two neuronal populations of this study. In studies of dietary restriction and aging, no differences in cell profile in aged rats in the total population, nitrergic subpopulation and glial cells, so this restriction was responsible for a decrease in the cellular profile in the total population and an increase in area were observed glial cells and no changes in the area of the nitrergic subpopulation. (Cirilo et al. 2013). With the death of myenteric neurons, the remaining nerve cells act in a compensatory manner to supply the same area of innervation with increase of cellular profile (Phillips et al. 2003). Thus, this increase of neuronal metabolic activity could lead to cellular death by apoptosis, characterized by a decrease of cellular profile.

The increase in the cellular profile area during aging process was described by many authors (Phillips et al. 2003, Peck et al. 2009). However, the increase in cellular profile measurements was not evident in the neurons NADPH-dp of the colon of the rats aged twelve months during aging 
(Gagliardo et al. 2008). Whereas a progressive increase exists during neuronal development to adulthood and, the plastic capacity of neurons throughout life, we suggest that changes in cell profile are less evident at older ages.

Through the neuronal labeling technique used in this study, we verified that the CR may be utilized as a preventive by minimizing the quantitative changes arising from aging on the ileum myenteric plexus. Thus, the maintenance of the enteric population by CR can prevent disorders of gastrointestinal tract attenuated by age, thus increasing the quality of life of elderly that according to world records is growing continually.

\section{ACKNOWLEDGMENTS}

This authors would like to thank the Fundação de Amparo à Pesquisa do Estado de São Paulo (FAPESP) for financial support (Process number 06/57369-2)

\section{RESUMO}

O envelhecimento é um processo biológico caracterizado por progressivos danos de estrutura e função dos sistemas orgânicos. No trato gastrointestinal, pode acometer o sistema nervoso entérico, o qual possui funções importantes na digestão e absorção de nutrientes causando aceleração do trânsito intestinal, reduzindo assim a sua função de absorção. A restrição calórica tem sido utilizada em vários estudos com a intenção de retardar os efeitos deletérios do envelhecimento. Este estudo teve como objetivo avaliar os efeitos da restrição calórica sobre os neurônios mioentéricos do íleo de 30 ratos durante o processo de envelhecimento. 30 ratos wistar foram agrupados da seguinte forma: GI (animais de 6 meses alimentados com dieta normal), GII (animais de 18 meses alimentados com dieta normal) e GIII (animais com idade de 18 meses com $31 \%$ de restrição calórica). Os ratos do grupo GI aos seis meses de idade e os animais do grupo GII e GIII foram eutanasiados após o período experimental de 12 meses, o íleo de todos os grupos foram coletados, medidos e processados pelas técnicas NADPH-d e acetilcolinesterase. A análise quantitativa dos neurônios revelou que o envelhecimento promove o aumento de neurônios mioentéricos NADPH-dp e reduz a população neuronal Acetilcolinesterase positiva. Entretanto, na área do perfil celular, não foram observadas diferenças significativas entre os grupos. A restrição calórica foi eficiente e pode ser utilizada como forma preventiva, uma vez que minimiza as alterações quantitativas associadas ao envelhecimento no plexo mioentérico do íleo.

Palavras-chave: envelhecimento, restrição calórica, plexo mioentérico, intestino delgado.

\section{REFERENCES}

Almeida CB And Fernandes MGM. 2001. Processo de pensamento alterado em idosos na vivência asilar. Rev Nursing 34: 22-25.

ANURAS S AND LOENING-BAUCKE V. 1984. Gastrointestinal motility in the elderly. J Am Geriatr Soc 32: 386-390.

BAILEY JW, WALKER E AND BEAUCHENE RE. 1993. Fatty acid composition of adipose tissue in aged rats-effects of dietary restriction and exercise. Exp Gerontol 28: 233-247.

BELAI A, COOPER S AND BURNSTOCK G. 1995. Effect of age on NADPH- diaphorase- containing myenteric neurons of rat ileum and proximal colon. Cell Tissue Res 279: 379-383.

Brogna A, Ferrara R, BUCCERI AM, LANTERI E AND CATALANO F. 1999. Influence of aging on gastrointestinal transit time. Invest Radiol 34: 357-359.

Butt WG, Wang M, Kaufman ST, Ryan JP AND COHEN S. 1993. Age-related changes in rat colon mechanics. Gastrointest Mot 5: 123-128.

Calabrese V, Mancuso C, Calvani M, Rizzarelli E, ButTerfield DA AND Stella A. 2007. Nitric oxide in the central nervous system: neuroprotection versus neurotoxicity. Nat Rev Neurosci 8: 766-775.

CAstelucci P, Souza RR, Angelis RC, Furness JB AND LIBERTI EA. 2002. Effects of pre and postnatal protein deprivation and postnatal refeeding on myenteric neurons of the rat large intestine: a quantitative morphological study. Cell Tissue Res 310: 1-7.

Cirilo CP, SCHOFFEN JPF, SANTI-RAMPAZZO AP, ZAPATER MCVU, ViCENTINI FA, COMAR JF AND NATALI MRM. 2013. Dietary restriction interferences with oxidative status and intrinsic intestinal innervation in aging rats. Nutr 29: 673-680.

Cortesini C, Cianchi F, Infantino A AND Lise M. 1995. Nitric oxide and VIP distribution in enteric nervous system in idiopathic chronic constipation. Dig Dis Sci 40: 2450-2455. 
COWEN T, JOHNSON RJR, SOUBEYRE V AND SANTER RM. 2000. Restricted diet rescues rat enteric motor neurons from age related cell death. Gut 47: 653-660.

Dolatshad NF, Silva AT, SOUBEyre V, Hoyle CHV, COWEN T AND SAFFREY MJ. 2001. Expression of the GDNF and its receptors in the aging gut. Soc Neuroscience Abtsr 27: 861-864.

FonTANA EA, WEAVER JR WD, DENBOW DM AND WATKINS BA. 1993. Early feed restriction of broilers: Effects on abdominal fat pad, liver, and gizzard weights, fat deposition, and carcass composition. Poultry Scien 72: 243-250.

Furlan MMDP, Molinari SL AND Miranda-Neto MH. 2002. Morphoquantitative effects of acute diabetes on the myenteric neurons of the proximal colon of adult rats. Arq Neuropsiquiatr 60: 576-581.

FuRnESS JB AND COSTA M. 1987. The Enteric Nervous System. Churchill Livingstone, Edinburgh.

FURNESS JB. 2006. The enteric nervous system. Blackwell Publishing, $1^{\text {st }}$ ed., Oxford: Blackwell Scientific Publications Ltd.

GABELLA G. 1971. Neuron size and number in the myenteric plexus of the newborn and adult rat. J Anat 109: 81-95.

Gagliardo KM, Clebis NK, Stabille SR, Mari RB, SousA JMA AND DE SOUZA RR. 2008. Exercise reduces inhibitory neuroactivity and protects myenteric neurons from agerelated neurodegeneration. Auton Neurosc Basic Clin 141: 31-37.

HAZZARD JP, BLASS WR, ETTINGER WH, HATTER JB AND OUS PANDER JP. 1999. Principles of Geriatric Medicine and Gerontology, $4^{\text {th }}$ ed., McGraw- Hill.

Holloszy JO AND Fontana L. 2007. Caloric restriction in humans. Exp Geront 42: 709-712.

JOHNSON RJR, SCHEMANN M, SANTER RM AND COWEN T. 1998. The effects of age on the overall population and on sub-populations of myenteric neurons in the rat small intestine. J Anat 192: 479-488.

KAPTEYN A. 2010. What can we learn from (about you) global aging? Dem 47:191-209.

KARNOVSKY MJ AND RoOTS L. 1964. A "direct-coloring" thiocholine method for cholinesterases. J Histochem Cytochem 12: 219-221.

KENYON C. 2005. The plasticity of aging: Insights from longlived mutants. Cell 120: 449-460.

LeE CK, Kloop RG, Weindruch R And Prolla TA. 1999. Gene expression profile ag aging and its retardation by caloric restriction. Sci 285: 1390-1393.

Letiembre M, Hao W, LiU Y, Walter S, Mihaljevic i, RIVEST S, HARTMANN T AND FASSBENDER K. 2007. Innate immune receptor expression in normal brain aging. Neurosci 146: 248-254.

LUKIW WJ. 2007. Micro-RNA speciation in fetal, adult and Alzheimer's disease hippocampus. Neuroreport 18: 297-300

MADSEN JL. 1992. Effect of gender, age and body mass index on gastrointestinal transit times. Dig Dis Sci 37: 1548-1553.
Mari RB, Clebis NK, Gagliardo KM, Guimarães JP, Stabille SR, Germano RM AND DE SOUZA RR. 2008. Effects of exercise on the morphology of the myenteric neurons of the duodenum of wistar rats during the ageing process. Anat Histol Embryol 37: 289-295.

MASORO EJ. 2002. Caloric Restriction: A key to understanding and modulating aging. Elsevier.

MATTSON MP. 2000. Apoptosis in neurodegenerative disorders. Nat Rev Mol Cell Biol 1: 120-129.

MERRY BJ. 2002. Molecular mechanisms linking calorie restriction and longevity. Int $\mathrm{J}$ Biochem Cell Biol 34: 1340-1354.

Mizuta Y, TAKahashi T AND OWYANG C. 1999. Nitrergic regulation of colonic transit in rats. Am J Physiol 277: 275-279.

NATALI MRM, MiRANDA-NetO MH AND ORSI AM. 2000. Ultrastructural features of myenteric ganglia of adult wistar rats (Rattus norvegicus). Anat Histol Embryol 29: 393-397.

NRC - NATIONAL Research Council. 1995. Nutrient requirements of laboratory animals. $4^{\text {th }}$ ed., Washington: Academic Press: 11-79.

Palo PE, Sell JL, Piquer J, Vilaseca L and Soto-Salanova F. 1995. Effect of nutrient restriction on broiler chickens 2. Performance and dibestivew enzyme activities. Poultry Scien 74: 1470-1483.

PAPA PC, SERAPHIM PM AND MACHAdO UF. 1997. Loss of weight restores GLUT 4 content in insulin-sensitive tissues of monosodium glutamate-treated obese mice. Int J Obes Relat Metab Disord 21: 1065-1070.

PAULA PC, VARGAS AM, SILVA JLT, NUNES MT AND MACHADO UF. 2002. GLUT4 protein is differently modulated during development of obesity in monosodium glutamate-treated mice. Life Sci 71: 1917-1928.

Peck Ma, Conrad MF, Kwolek CJ, Lamuraglia G, PARUCHURI V AND CAMBRIA RP. 2009. Intermediate-term outcomes of endovascular treatment for symptomatic chronic mesenteric ischemia. J Vasc Surgery 51:140-147.

PEKAS JC. 1993. Maintenance feeding of $100 \mathrm{~kg}$ pigs: effect on carcass lean and fat yield and on gastrointestinal organ size. Anim Prodet 57: 455-464.

PhILliPs RJ, KiefFer EJ AND Powley TL. 2003. Aging of the myenteric plexus: neuronal loss is specific to cholinergic neurons. Auton Neurosc 106: 69-83.

Phillips RJ, KiefFer EJ AND POWLey TL, 2004. Loss of glia and neurons in the myenteric plexus of the aged Fischer 344 rat. Anat Embryol 209: 19-30.

PHILLIPS RJAND POWLEY TL. 2001. As the gut ages: Timetables for aging of innervations vary by organ in the Fischer 344 rat. J Comp Neurol 434: 358-377.

PHILLIPS RJ AND POWLEY TL. 2007. Innervation of the gastrointestinal tract: Patterns of aging. Auton Neurosc 136: 1-19.

PIPER MD AND BARTKE A. 2008. Diet and aging. Cell Metab 8: 99-104. 
Porto GS, Pereira JNB, Tibúrcio VG, Stabille SR, FAria HG, GERMANO RM AND MARI RB. 2012. Effect caloric restriction on myenteric neuroplasticity in the rat duodenum during aging process. Auton Neurosc 168: 43-47.

Riggs BL, Melton LJ And RobB RA. 2004. Population-based study of age and sex differences in bone volumetric density, size, geometry, and structure at different skeletal sites. J Bone Miner Res 19: 1945-1954.

SANDERS KM AND WARD SM. 1992. Nitric oxide as a mediator of nonadrenergic noncholinergic neurotransmission. Am J Physiol 262: 379-392.

SANTER RM. 1994. Survival of the population of the NADPHdiaphorase stained myenteric neurons in the small intestine of aged rats. J Auton Nerv Syst 49: 115-121.

SCHERER-Singler U, Vincent SR, Kimura H AND MCGEER EG. 1983. Demonstration of unique population of neurons with NADPH-diaphorase histochemistry. J Neurosci Methods 9: 229-234.

SHAMBUREK RD AND FARRAR JT. 1990. Disorders of the digestive system in the elderly. N Engl J Med 322: 438-443.

SingH S AND DiKshit M. 2007. Apoptotic neuronal death in Parkinson's disease: Involvement of nitric oxide. Brain Res Rev 54: 233-250.
SOHAL RS AND WEINDRUCH R. 1996. Oxidative stress, caloric restriction, and aging. Sci 273: 59-63.

SOUZA RR, MORATELli HB, BORGES N AND LIBERTI EA. 1993. Age-induced nerve cell loss in the myenteric plexus of the small intestine in man. Int J Exp Clin Gerontol 39: 183-188.

Thrasivoulou C, Soubeyre V, Ridha H, Giuliani D, Giaroni C, Michael GJ, SAFFrey MJ AND COWEN T. 2006. Reactive oxygen species, dietary restriction and neurotrophic factors in age-related loss of myenteric neurons. Aging cell 5: 247-257.

UN - United NATiOns. 2009. World Population Ageing, New York, 89.

WADE PR AND COWEN T. 2004. Neurodegeneration: a key factor in the ageing gut. Neurogastroenterol Motil 16: 19-23.

WEINDRUCH RH AND WALFORD RL. 1988. The Retardation of Aging and Disease by Dietary Restriction. Springfield.

Xiong Z, Sperelakis N, Noffsinger A AND FenoglioPREISER C. 1995. Ca2+ currents in human colonic smooth muscle cells. Am J Physiol 269: 378-385. 